\title{
Exploring the Mediated and Moderated Effects of Operator Service Quality on Customer Retention: Evidence from Taiwan's Mobile Market
}

\author{
Chun-Mei Chen \\ Department of Business Administration \\ China University of Technology, Taiwan (R.O.C.) \\ E-mail: doris888@cute.edu.tw
}

Received: May 23, 2017

Accepted: August 7, 2017

Published: October 1, 2017

doi:10.5296/jmr.v9i4.11589

URL: https://doi.org/10.5296/jmr.v9i4.11589

\begin{abstract}
The goal of this research is to explore how service quality affects perceived value and customer retention by adding the effects of the Big Five personality traits on the five Taiwan-based mobile service providers. The study analyzes the data by applying structural equation modeling (SEM) from 620valid questionnaires surveyed in the greater Taipei region. The empirical results corroborate that the direct effect of SQ (service quality) is positively related to PV (perceived value), and PV is positively related to CR (customer retention). The PV positively mediates the relationship between the SQ and CR. For the indirect effect of SQ-PV-CR by adding the Big Five personality traits factor we observe a partial moderated effect. The strategic implications for the mediator of perceived value and the moderator of customer personality traits contribute to scholarly advancement of knowledge and the state of managerial practice.
\end{abstract}

Keywords: service quality, perceived value, customer retention, personality traits, wireless 


\section{Introduction}

The hot topic of 'continuing to use' or 'deciding to switch to another operator' for mobile subscribers is the most concerned issue for the global wireless communications industry. By pursuing business performance, how the enterprises enhance service quality and bring their customers better recognition of perceived value will guide customers to select them over competitors. The demands for mobile communications and computing continue their dramatic growth, driven by the proliferation of smart phones and tablets (Dickinson, 2015). Following the integrated applications of voice, data and multi-media, the various content should be carried on the mobile service providers' (operators') platforms. The free charge offerings for voice and short messages services (SMS) could be globally connected through Wi-Fi nodes, Bluetooth, etc. via worldwide local area networks (WLAN).

On October 15, 2005, the Ministry of Transportation and Communications in Taiwan announced the implementation of the number portability [NP] service (MTC, Taiwan). The mobile operators adopted flat rate pricing strategies to bundle data and voice usage to meet the needs of the high demand consumers, and to further attract the subscribers in rival mobile operators to switch to their network via NP. In 2015, Taiwan's smart phone users used the mobile application 'LINE' to spend an average of 71.8 minutes per day which was higher than the60.5 minutes reported for use on the Facebook APP (MIC, Taiwan).Moreover, in 2014, the average time spent on the mobile Internet per day for Taiwan users was the highest in the world and the monthly average transit bandwidth was 14GB [gigabytes] (Millward Brown websites). Therefore, Taiwan is an important indicator to observe what factors attract mobile subscribers to 'stay' with the current operators or 'not to stay' and switch to competing mobile operators, which served as the basis to formulate the motivations of this study.

The market competition between mobile operators has dramatically intensified and the delivery of high-quality services is a key priority for the operators. The prior literature studies focused on customer-oriented marketing concepts to explore how service quality affects customer satisfaction and continued use, which has been consistently explored(Cronin \& Taylor, 1992; Yang \& Fang, 2004).Fredericks and Slater (1998) indicated that service quality, brand image, perceived value, customer satisfaction and loyalty are highly related, and the recognition of perceived value derived from brand image all affect customer loyalty. Service quality and customer satisfaction are related to customer loyalty in terms of behavioral intentions (Cronin et al., 2000; Caruana, 2002). Gerpott et al. (2001) proposed that customer retention, loyalty, and satisfaction should be treated differently and as causally inter-linked constructs.

Hossain and Dwivedi (2015) investigated the role of confirmation through direct, mediating and moderating effects, and validated that service quality is evaluated in the confirmation stage to affect customer satisfaction (CS), the customers' continuance intention (CI), and the confirmation moderates the relationship between CS and CI. Chen and Liu (2017a)explored that brand image and perceived value mediate the effect of service quality on customer 
loyalty to display a distal effect. Chen and Liu (2017b) applied structural equation modeling to propose the 'competitive position' in the mobile industry to be a moderating variable between customer satisfaction and customer retention.

This is the first study to add the 'personality traits' factor to observe the direct and indirect effects in service quality satisfaction to influence perceived value and customer retention in the mobile service industry. This research adopts Taiwan's five major wireless communications carriers as the study object to explore how consumers choose among the numerous options and promotional offers including network capacity, service quality and competitive price programs offered by the mobile operators. The goal of this paper is to provide mobile operators summaries on how to retain customers and improve management performance, and to serve as a reference for academia, mobile operators and regulation policy makers.

\section{Taiwan mobile industry development}

\subsection{Taiwan mobile market}

In 2002, Taiwan's mobile penetration rate had reached $108 \%$ which was the world's number one ranking for mobile penetration by country. By the end of 2016, the number of Taiwan mobile subscribers had reached 28.929 million, and the penetration rate was as high as $120.7 \%$ (NCC, Taiwan). 4G technology was specifically designed for superior data transmission offering faster Internet access for activities such as video conferencing and multi-player online games (Chen and Liu, 2017b). In 2016, Taiwan's4G network was the major utilized network technology and it accounted for $67 \%$ of the mobile subscribers, while subscribers on $3 \mathrm{G}$ networks accounted for $32 \%$, and the $2 \mathrm{G}$ network business had ceased operations since June 30, 2017 (NCC, Taiwan).Popular mobile applications (Apps) promoted mobile Internet growth. Chiao (2017) investigated that each of Taiwan's mobile phone users had on average 16 self-downloaded (non-preinstalled) applications.

Since 2012, the mobile revenue derived from voice and short messages had obviously decreased (NCC, Taiwan)due to being replaced by the prevailing of OTT (over-the-top) ${ }^{1}$ services. The popular social network service (SNS) such as LINE, Skype, Whats App, Facetime, and others are all OTT services, which make it easy to have phone calls or send instant messages based on a free charge model when connected to the Internet. Due to strong market competition, the mobile operators have tried to improve their service quality and adopt lower prices to maintain customer retention and attract the rival customers to switch to their mobile network.

The mobile operators have been staring at the churn rate every day for timely response to market competitive changes. The churn rate is characterized by some proportion of contractual subscribers transferring to other operators due to customer dissatisfaction, price sensitivity, being attracted by better offers from other mobile carrier rivals. A high churn rate

\footnotetext{
${ }^{1}$ OTT (over-the-top) means to pass over the telecom service providers, to bypass the traditional telecom network and go through the Internet to provide application services and media-related services.
} 
for a mobile operator represents that the amount of outflow subscribers is always greater than the inflow subscribers. Ahn et al. (2006) proposed that service providers should reduce their churn rate, because negligence could result in lower profitability. Taiwan's mobile operators have continued to strive for customer retention to prevent customer churn from their $4 \mathrm{G}$ service pricing wars.

\subsection{Mobile operator analysis}

After a series of mergers and acquisitions for Taiwan's small-scale mobile operators, in 2016five mobile operators are still in operation. Chunghwa Telecom (hereinafter referred to as CHT)is the leading mobile operator, the second is Taiwan Mobile Telecom (hereinafter referred to as TWM) and the third is FarEast Telecom (hereinafter referred to as FET) to occupy a total market share of $88 \%$ (NCC, Taiwan). The smaller market players are Asia Pacific Telecom (hereinafter referred to as APT) and Taiwan Star Telecom (hereinafter referred to as TStar) to own the remaining market share of $12 \%$.

CHT was originally affiliated with state-owned institutions, and their mobile base stations, mobile handsets and other equipment needed to be publicly bided with bureaucratic procedures. Therefore, there had accumulated about 1 million pending users to wait for mobile phone numbers. In 1998, when TWM and FET officially launched their mobile business, each of them easily received and served about 500 thousand mobile users to establish the positions of Taiwan's three first-movers. TWM firstly adopted a zero-dollar handset promotional offer to bundle with mobile phone numbers based on a flexible low-cost strategy. In December 2000, TWM had 5.14 million subscribers, which was greater than CHT's4.66 million subscribers to be the leading mobile operator in Taiwan at that period(Statistics Department of MTC). Thereafter, CHT applied a full-employee marketing strategy to set a target of recruiting six mobile phone numbers per employee to accumulate about 600 thousand subscribers in a short four-month time span. In December 2001, CHT reported having 6.23 million subscribers, which was greater than TWN's 5.6 million subscribers to regain the market leader position (Statistics Department of MTC).

The mobile market followers consist of APT and TStar. The NCC allowed AMBIT Corporation, which was a subsidiary of Hon-Hai Technology Group to be merged into the new Asia-Pacific Telecom. Thus, Hon-Hai Technology Group holds 22\% of the new APT shareholding and TWM owns 3\% of the new APT shareholding (APT website, Annual Report).APT originally purchased $3 \mathrm{G}$ equipment to serve the CDMA system solution, which differed from the global mainstream WCDMA system solution. It resulted in APT subscribers to lose due to system connections with hysteresis, and few handsets were compatible with this solution.

Vibo Telecom was acquired by TStar, which is primarily owned by the Ting Hsin International group. Due to the previous media reported rancid oil events of the parent company, it affected TStar's image to result in loses of subscribers. However, TStar adopted flexible and lower pricing strategies than the other competitors, claimed that its subscriber numbers were improving with net inflows during 26 consecutive months. In June 2017, TStar announced it had 1.73 million 4G subscribers surpassed APT's1.7 million subscribers (TStar 
websites). In 2016, Taiwan's 3G and 4G subscriber mobile operators market share is shown in Table 1:

Table 1. 3G and 4G subscriber market shares of mobile operators in 2016

\begin{tabular}{lcc}
\hline Mobile operators/market share & 3G subscribers & 4G subscribers \\
\hline Chunghwa Telecom & $36.2 \%$ & $37.3 \%$ \\
Taiwan Mobile & $27.1 \%$ & $24.9 \%$ \\
FarEast Telecom & $26.2 \%$ & $25.2 \%$ \\
Asia Pacific Telecom+TStar Telecom & $10.5 \%$ & $12.6 \%$ \\
\hline
\end{tabular}

Source: NCC, Taiwan

\section{Literature review and hypotheses}

\subsection{Service quality satisfaction}

The end customer's satisfaction level of service quality (hereafter named 'service quality satisfaction') measures the satisfaction level for the government's and the private sectors' offerings. A comparison of consumer expectations with performance to build up service quality perception and evaluation depends on the process and outcome of service delivery (Parasuraman et al., 1985). 'Service quality' was defined to assess the customers about a product's overall excellence or superiority (Zeithaml, 1988). Parasuraman et al. (1988) proposed the SERVQUAL scale which is composed of tangibles, reliability, responsiveness, assurance and empathy to measure the satisfaction of service quality based on importance ranking. Nevertheless, many researchers have questioned its widespread adoption to measure all industries and said it should be modified (Cronin \& Taylor, 1992; Culiberg, 2010).

Voss et al. (1998) indicated that customer satisfaction should be composed of service satisfaction, emotional satisfaction and price satisfaction. Kristensen et al. (1999)indicated that customers should achieve true satisfaction with the inferred quality and value of goods/services. Service quality has a significant impact on business performance, business costs, customer satisfaction, customer loyalty and profitability(Seth et al., 2005). The customer satisfaction is the leading criterion for determining quality, including satisfaction with the quality of a product, an ongoing business relationship, and the price or performance ratio to meet customer expectations(Lee, 2006).

Clemes et al. (2008) indicated that for achieving a high level of satisfaction, a high standard of service quality should be delivered by the service provider. Lai and Chen (2011) conceptualized relationships among service quality, perceived value, satisfaction, and passenger behavioral intentions. The greatest concern in the service industry is how to make their subscribers feel satisfied and prevent them from switching to rival companies (Chen \& Liu, 2017b). Thus, a key point is that satisfaction means that the enterprise must deliver comparable or greater value than the consumers initially expected, and to offer enough to cope with their needs.

\subsection{Perceived value}


Dodds and Monroe (1985) identified the relationship models of price, perceived quality, and perceived value and mentioned that perceived value is an important factor in the consumer purchasing decision process. Zeithaml (1988) proposed that perceived value is what the customer gains from the product to compare it with the out-paying cost. Parasuraman and Grewal (2000) indicated that perceived value is an important index for those customers in repurchasing considerations. Gordon and McDougall (2000) revealed that core service quality (the promise) and perceived value were the most important drivers of customer satisfaction.

Sweeny and Soutar (2001) induced the construct of perceived value, which includes the four dimensions of perceived quality, emotional value, social value, and price to develop the PERVAL scale.Petrick (2002) proposed that perceived value of service comprises five dimensions: quality, emotional response, monetary price, behavioral price and reputation. Raquel and Ángeles (2007) indicated that the perceived value is the interaction between the consumer and the product. Customer-perceived value is the difference between a prospective customer's evaluation of a product's benefits and costs when compared with other products (Sanchez-Fernandez \& Iniesta-Bonillo, 2007).

During the process of consuming a product or service, how to satisfy the consumer's perceived value and further to garner a good impression on the corporation is a very important issue for enterprises (Kuo et al., 2009). The website owners should not only improve their e-service quality, but also emphasize customer perceived value (Chang et al., 2009).Mobile operators should estimate which offerings can provide the greatest perceived value for their customers (Chen \& Liu, 2017b). Thus, customer perceived value come from the service quality value of the offerings which are provided by the enterprises, and further to affect continuous usage intentions.

\subsection{Customer retention}

Customer retention (CR) is a crucial area of study in the field of relationship marketing that is mainly concerned with keeping customers for the long term (Grönroos, 1997). 'Customer retention' is an assessment of the product/service quality provided by a business that measures how loyal customers are (Business Dictionaries websites). Satisfaction is an important indicator to influence the users to continue the usage intention (Oliver, 1980; Oliver \& Bearden, 1985). 'Usage intention' is the willingness to implement certain business practices for the user (Fishbein \& Ajzen, 1975). Sathye (1999) indicated that the increase in the operation convenience and in the consuming process would convince the consumers to enhance their usage intention and product acceptance.

Boulding et al. (1993) proposed that the perceived services quality for the customer will affect the overall assessment of satisfaction, and thus will impact the follow-up customer retention. For managing long-term relationships with customers, it is essential for businesses to identify and nurture a satisfactory, mutually beneficial, continuous relationship with consumers to enhance customer retention (Metcalfet al., 1992; Buttle, 1996).Anderson and Sullivan (1993) pointed out that the consumers feel a degree of satisfaction from the previous experience of products or services, which will affect customer retention. Venetis and Ghauri 
(2004) proposed that service quality is considered as a major determinant in customer retention and in building value relationships.

Moreover, Gounaris (2005) attempted an investigation of two specific antecedents of trust and commitment influences on the customer retention for the perceived quality of the service and the customer bonding techniques. The customer retention is mainly decided by the perceived satisfaction level of service quality after the consuming experience. Andic (2006) stated that the major mobile network operators in the UK, including Orange, T-Mobile, O2 and Vodafone, lose over a third of their youth subscribers to rival providers.

Eshghi et al. (2007) suggested that wireless service providers are better off improving customer satisfaction to minimize customer defection. They further implied that shifting scarce resources to customer retention through improved services, saving costs for expensive customer acquisition campaigns might be recommended strategies.Hu et al. (2009) indicated to deliver high quality services and created superior customer value, which can result in achieving high satisfaction, thus affecting the firm's corporate image and leading to consumer retention. In the mobile phone market, $\mathrm{CR}$ becomes an essential phenomenon since this sector has witnessed substantial growth, change, and competition (Alshurideh, 2016).

Galetto (2015) indicated that the goals of 'customer retention' programs are to help companies secure as many customers as possible, often through loyalty and brand loyalty initiatives. Alshurideh $(2016,2017)$ studied customer-retention behavior in the contractual and non-contractual mobile purchasing settings is essential, especially when the goal is to establish long-term customer relationships. How to prevent existing high ARPU subscribers from switching to competitors in the mobile industry is a very important issue. Thus, a common focus in this industry is how to keep a higher retention rate for current subscribers, thus decreasing the churn rate and attracting the rival's subscribers to transfer to their services.

\subsection{Personality traits}

The Big Five personality traits have been known as the Five-Factor Model (FFM) which is a model based on common language descriptors of personality traits. The FFM of personality could be understood by positing that all people have certain traits, or characteristic ways of behaving themselves. In 1963, Allport and Odbert divided them into four categories with 4,500 personality traits types based on Webster's New International Dictionary (1925 edition)(Goldberg, 1993). By using the 1961 edition of Webster's International Dictionary, Norman added relevant terms and removed some from All port and Odbert's list, and the study of Goldberg in 1981 formally renamed the personality traits as the 'Big Five' factor structure (Goldberg, 1993).

McCrae and Costa (1987) assembled the 'Big Five personality traits', and since then, it has been widely accepted by psychologists as the five-character model or FFM. Goldberg (1993) indicated that this theory uses descriptors of common language and therefore suggests five broad dimensions used by the common public to define the human personality and psyche. 
Toegel and Barsoux (2012) described the detailed characteristics of the 'Big Five personality traits' as below:

(1) Neuroticism: The tendency to experience unpleasant emotions easily, such as anger, anxiety, depression, and vulnerability. Neuroticism also refers to the degree of emotional stability and impulse control.

(2) Extraversion: Energy, positive emotions, urgency, assertiveness, sociability and the tendency to seek stimulation in the company of others, and talkativeness.

(3) Openness to experiences: Openness reflects the degree of intellectual curiosity, creativity and a preference for novelty and variety a person has.

(4) Agreeableness: A tendency to be compassionate and cooperative to measure one's trusting and helpful nature, and whether a person is generally well tempered or not.

(5) Conscientiousness: A tendency to be organized and dependable, show self-discipline, act dutifully, aim for achievement, and prefer planned rather than spontaneous behavior.

The FFM theory has been extensively adopted for the research of personality traits. It has been identified in the application of different tools to capture most of the personality differences. Zhou and Lu (2011) showed that extraversion has a strong effect on trust, whereas neuroticism has significantly negative effects on trust and perceived usefulness, both of which determine user intention to adopt mobile commerce. Santhanamery and Ramayah (2013) proposed to investigate the effect of personality traits in encouraging the continued use of the e-filing system in Malaysia. Srisawatsaku, et al. (2014)aimed to enhance the understanding of the relationship between the 'big five personality traits' and the usage and purchase intention of mobile applications in different categories. Thus, by adding in the different personality traits of mobile subscribers to observe the indirect effects of SQ-PV-CR deserves to be explored.

\section{Research method}

\subsection{Research structure}

This study explores the effects of service quality satisfaction on customer retention through the mediator of perceived value in Taiwan's mobile market. The measurement of customer personality is to apply the 'Big Five personality traits', which consists of neuroticism, extraversion, openness to experience, agreeableness and conscientiousness (McCrae \& Costa, 1987). The respondents answered to their own personality inclinations, which is according to their self-recognition feedback in choosing one of five personality traits to best describe themselves.

This study is based on the theoretical architecture proposed by Fredericks and Slater (1998)to explore the direct effects of SQ-PV and PV-CR and the indirect effects of SQ-PV-CR by adding the variables of the five personality traits. The measurement of service quality satisfaction is based on the SERVQUAL model and it consists of tangibility, reliability, responsiveness, assurance and empathy (Parasuraman et al., 1988). Please refer to the 
question items 1-15 in Appendix 1.The concept of perceived value contains recognized quality, emotional value, social value and price (Sweeny \& Soutar, 2001). Please see question items 16-23 in Appendix 1.The measurement of customer retention is included for the recent buying behavior; repurchase intention and recommendation intention (Jones \& Sasser, 1995). Please see question items24-28inAppendix 1.The research framework is shown in Fig. 1:

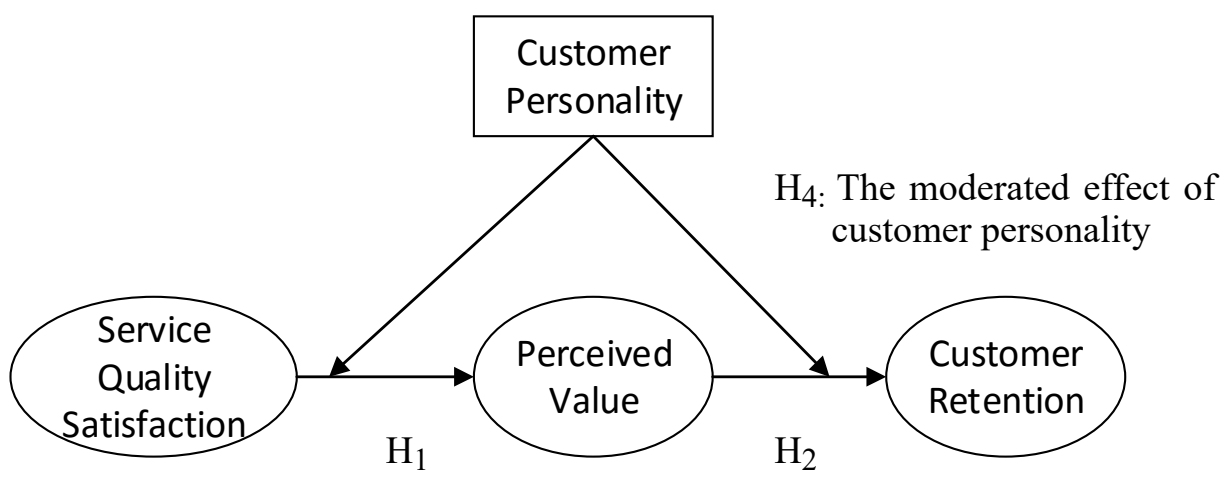

Fig. 1. Research framework

$\mathrm{H}_{3}$ : The mediated effect of perceived value

H1: Service quality satisfaction is positively related to perceived value.

H2: Perceived value is positively related to customer retention.

H3: Perceived value positively mediates the relationship between service quality satisfaction and customer retention.

H4: Customer personality traits partially moderate the relationship between the customer quality satisfaction and customer retention through perceived value.

\subsection{Sample analysis}

This market survey was conducted to investigate the mobile users mainly living in the Greater Taipei regions of Taipei City and New Taipei City. The survey locations of the Greater Taipei regions included Wan-fang Hospital, the Danshui MRT Station, the Taipei Main Station, the Taiwan University campus gate area on Roosevelt Road, the Gon-guan area, the World Trade Center, the Taipei Eastern Distinct, the Xi-men-ding area and other locations. The survey was conducted from the beginning of January to the end of February in 2017. The questionnaire ratio was roughly distributed based on the market share of five mobile service providers to make a visit for the respondents. This sampling method is taken to be as a convenient sampling based on a Likert 1-5 scale from a 'very satisfied' score of 5 to a 'very dissatisfied' score of 1 . 


\section{Macrothink}

Journal of Management Research

ISSN 1941-899X

2017, Vol. 9, No. 4

The sample survey of this study is based on the existing subscribers of the five mobile operators in Taiwan to answer the questionnaire. A total of 700 copies of the questionnaire were distributed in face-to-face inquires, and 626 valid samples were recovered. The recovery rate was about $89.4 \%$. The valid samples included 182 copies for CHT, and the customer responders of TWM and FET had 162 copies each. The valid samples from APT and TStar had 60 copies each. The sample structure of the respondents is analyzed and is shown in Table 2.

Table 2. The sample structure of the respondents

\begin{tabular}{llrr}
\hline Variables & Categories & $\mathrm{n}$ & $\%$ \\
\hline Gender & Male & 285 & 45.5 \\
Age & Female & 341 & 54.5 \\
& Under 18 (including) & 65 & 10.4 \\
& $19-30$ & 342 & 54.6 \\
& $31-45$ & 114 & 18.2 \\
Education degree & $46-55$ & 68 & 10.9 \\
& 56+ & 37 & 5.9 \\
& Junior high school or lower & 42 & 6.7 \\
Occupation & High school (Vocational) & 150 & 24.0 \\
& University (College) & 417 & 66.6 \\
& Master's degree and above & 17 & 2.7 \\
& Military \&Government & 18 & 2.9 \\
& Service industry & 111 & 17.7 \\
& Financial,Insurance\& Business & 90 & 14.4 \\
& Technology industry & 25 & 4.0 \\
& Students & 277 & 44.2 \\
Housekeeping & 13 & 2.1 \\
Monthly Income (NT\$ & Less than 20,000 & 12 & 1.9 \\
/average) & Unemployed & 37 & 5.9 \\
& Others & 300 & 47.9 \\
& 30,001 50,000 00 元 & 157 & 25.1 \\
& 50,001 80,000 & 130 & 20.8 \\
& 80,001 & 32 & 5.1 \\
& New Taipei City & 7 & 1.1 \\
& Taipei City & 217 & 34.7 \\
& Other Counties & 296 & 47.3 \\
& & 113 & 18.0 \\
\hline \multirow{5}{*}{ Soul } & &
\end{tabular}

Source: This study

\subsection{Data Analysis}

\subsubsection{Confirmatory factor analysis}

For conducting an appropriate examination of the research hypotheses, this study follows a two-step approach from Anderson and Gerbing (1988), to apply confirmatory factor analysis (CFA) to assess properties of the measurement model, and then it subsequently tests the 
hypotheses. In the validation of the measurement model, the three reliability measures including Cranach's $\alpha$, composite reliability, and the average variance extracted (AVE) estimator are employed to assess scale reliability. The results of CFA indicated that Cronbach's alpha and the composite reliability range from 0.766 to 0.886 . Moreover, for each latent construct, the average variance extracted is close to or over 0.5 , representing that the minimum acceptable values reach all the constructs and that the scale of this study has appropriate reliability. Table 3 shows the summary of the reliability analysis results.

Table 3. Measurement model summary

\begin{tabular}{|c|c|c|c|c|c|c|c|}
\hline Constructs & Items & Mean & $\mathrm{SD}$ & $\begin{array}{l}\text { Standardized } \\
\text { loading }\end{array}$ & $\begin{array}{c}\text { Cronbach } \\
\text { alpha }\end{array}$ & $\begin{array}{l}\text { Composite } \\
\text { reliability }\end{array}$ & $\begin{array}{c}\text { AVE } \\
\text { estimate }\end{array}$ \\
\hline \multirow{5}{*}{$\begin{array}{l}\text { Service quality } \\
\text { satisfaction }\end{array}$} & Tangible attributes & 3.626 & 0.572 & $0.732^{* * *}$ & \multirow{5}{*}{0.884} & \multirow{5}{*}{0.886} & \multirow{5}{*}{0.609} \\
\hline & Reliability & 3.440 & 0.699 & $0.747^{* * *}$ & & & \\
\hline & Responsiveness & 3.591 & 0.616 & $0.769^{* * *}$ & & & \\
\hline & Assurance & 3.556 & 0.628 & $0.846^{* * *}$ & & & \\
\hline & Empathy & 3.581 & 0.622 & $0.803^{* * *}$ & & & \\
\hline \multirow[t]{4}{*}{$\begin{array}{l}\text { Perceived } \\
\text { value }\end{array}$} & $\begin{array}{l}\text { Perceived quality } \\
\text { value }\end{array}$ & 3.523 & 0.620 & $0.744^{* * *}$ & \multirow{4}{*}{0.825} & \multirow{4}{*}{0.825} & \multirow{4}{*}{0.541} \\
\hline & Emotional value & 3.599 & 0.644 & $0.721^{* * *}$ & & & \\
\hline & Social value & 3.494 & 0.643 & $0.747^{* * *}$ & & & \\
\hline & Price & 3.593 & 0.635 & $0.731^{* * *}$ & & & \\
\hline \multirow{2}{*}{$\begin{array}{l}\text { Customer } \\
\text { retention }\end{array}$} & Repurchase intention & 3.600 & 0.691 & $0.804^{* * *}$ & \multirow[b]{2}{*}{0.766} & \multirow[b]{2}{*}{0.852} & \multirow[b]{2}{*}{0.744} \\
\hline & $\begin{array}{l}\text { Recommendation } \\
\text { intention }\end{array}$ & 3.571 & 0.764 & $0.917^{* * *}$ & & & \\
\hline
\end{tabular}

${ }^{* * *} p<0.01$

Next, the two major indicators including convergence and discriminate validities are employed to assess scale validity. As depicted in Table 3, the standardized loadings of all items for each construct are significant at the 0.05 level, representing that the scale of this study has an appropriate level of convergence validity and provides more explanatory power than the error variance. Regarding the testing of discriminate validity, this study utilizes the $\chi^{2}$ difference test to verify it. The methodology of the $\chi^{2}$ difference test is used to calculate the differences between the full model, where all correlations are free to be estimated, and the restricted model, in which the correlation of assessed constructs is constrained to be in unity and others are permitted to be free. If all estimates of the $\chi^{2}$ difference test for each pair of constructs are significant, then the discriminant validity is concluded to exist (Bagozzi et al., 1991). Table 4 summarizes the results examining the discriminant validity. The results confirm that all estimates of the $\chi^{2}$ difference tests for any pair of constructs are significant at the level of 0.05 ( $\chi^{2}$ difference $\left.>3.84\right)$, exhibiting that the scale of this study has a sufficient level of discriminant validity. 
Table 4. Results of the discriminant validity $\left(\chi^{2}\right.$ difference test)

\begin{tabular}{lcc}
\hline Latent constructs & Service quality satisfaction & Perceived value \\
\hline Perceived value & $103.312^{* *}$ & - \\
Customer retention & $81.742^{* * *}$ & $17.754^{* *}$ \\
\hline$* * 0.001$ &
\end{tabular}

After the reliability and validity of the scale have met the criteria, the relevant indices of goodness of fit for overall model are further considered. Among these fit measures, $\chi^{2} / \mathrm{df}$ is 3.663, the goodness of fit (GFI) is 0.957 , the comparative fit index (CFI) is 0.972 , the normed fit index (NFI) is 0.962 , and the non-normed fit index (NNFI) is 0.962 . The results of all these indices are above the acceptable value of 0.9. In addition, the standardized the root mean square residual (SRMR) of 0.024 and the value of root mean square error of approximation (RMSEA) of 0.065 are significantly below the suggested values of 0.05 and 0.08 , respectively. These indices indicate that the measurement model is adequate, demonstrating that the measurement model of the theoretical framework provides an appropriate fit with the actual data. Therefore, the hypothesized measurement model is reliable and meaningful to test the mediation and moderation effects among the constructs.

\subsubsection{Testing of the direct and mediated effects}

Table 5 indicates that the direct effect of SQ on PV is 0.956 , the $p$-value $<0.001$ and a $95 \%$ bootstrap confidence interval based on 2,000 bootstrapped samples is 0.838 to 1.074, providing support for Hypothesis 1. The results indicate that the superior customer satisfaction for service quality resulted in increasing the customer perceived value. Next, the direct effect of PV on CR is 1.128 and a $95 \%$ bootstrap confidence interval based on 2,000 bootstrapped samples is 0.993 to 1.263 , providing support for Hypothesis 2. These results indicate that superior customer perceived value lead to greater customer retention. Moreover, to explore the indirect relationship between SQ and CR, perceived value is considered as the mediator and it's estimating and testing is conducted using a bootstrapping approach. In the SQ-PV-CR model, the indirect effect is $1.078(p<0.001)$ and the $95 \%$ bootstrap confidence interval is 0.927 to 1.230 , providing support for Hypothesis 3 . The results imply that perceived value is a mediator of service quality and customer retention, and suggest that the customer repurchase and recommendation intentions could be driven by the superior customer satisfaction of service quality. 
Table 5. Estimating and testing of indirect effects

\begin{tabular}{llc}
\hline Effects & Coeff. (SE) & 95\% CI \\
\hline $\mathrm{SQ} \rightarrow \mathrm{CR}$ & & \\
Direct effect & & \\
$\mathrm{SQ} \rightarrow \mathrm{PV}$ & $0.956(0.060)^{* * *}$ & {$[0.838,1.074]$} \\
$\mathrm{PV} \rightarrow \mathrm{CR}$ & $1.128(0.069)^{* * *}$ & {$[0.993,1.263]$} \\
Indirect effects & & \\
$\mathrm{SQ} \rightarrow \mathrm{PV} \rightarrow \mathrm{CR}$ & $1.078(0.077)^{* * *}$ & {$[0.927,1.230]$} \\
\hline
\end{tabular}

Note: 2,000 bootstrap samples; ${ }^{* * *} p<0.01$.

\subsubsection{Test of the moderated effect}

To explore if the indirect effects of SQ-PV-CR were conditional on the customers' personality traits, this study conducts pairwise comparisons of indirect effects for all personality traits. Table 6 indicated that all indirect effects of SQ-PV-CR for each personality trait are positively significant, and the results echo the test of Hypothesis 3 and provides robust testing for the relationship among service quality, perceived value and customer retention. Moreover, regarding the effect of personality traits on the variety of SQ-PV-CR, Table 6 indicates that two of the 10 pairwise comparisons have significant differences. One is the indirect effect between Extraversion and Neuroticism; the difference is 0.470 and is significant at a 0.1 level. The other is the indirect effect between Openness to experiences and Neuroticism, the difference is 0.502 and has a 0.05 significance level. Although there are only two differences, which are significant in the personality traits, however, the indirect effect will vary due to different personality traits to display a partially moderated effect. These two contrasts partly provide evidence for supporting Hypothesis 4whichposits the effects of service quality satisfaction on customer retention via perceived value might be conditional on customer personality traits. 
Table 6. Indirect effects across the levels of personality traits

\begin{tabular}{lcc}
\hline & Coeff. (SE) & $95 \%$ CI \\
\hline Neuroticism & Indirect effects & \\
Extraversion & $0.679(0.220)^{* * *}$ & {$[0.248,1.110]$} \\
Openness to experience & $1.149(0.130)^{* * *}$ & {$[0.893,1.404]$} \\
Agreeableness & $1.181(0.135)^{* * *}$ & {$[0.917,1.445]$} \\
Conscientiousness & $1.048(0.092)^{* * *}$ & {$[0.868,1.288]$} \\
& $1.006(0.122)^{* * *}$ & {$[0.766,1.246]$} \\
Extraversion vs. neuroticism & Contrasts & \\
Openness vs. neuroticism & $0.470(0.247)^{*}$ & {$[-0.014,0.953]$} \\
Agreeableness vs. neuroticism & $0.502(0.245)^{* *}$ & {$[0.022,0.983]$} \\
Conscientiousness vs. neuroticism & $0.369(0.228)$ & {$[-0.078,0.817]$} \\
Openness vs. extraversion & $0.327(0.250)$ & {$[-0.163,0.818]$} \\
Agreeableness vs. extraversion & $0.033(0.165)$ & {$[-0.291,0.356]$} \\
Conscientiousness vs. extraversion & $-0.101(0.140)$ & {$[-0.375,0.174]$} \\
Agreeableness vs. openness & $-0.101(0.140)$ & {$[-0.462,0.178]$} \\
Conscientiousness vs. openness & $-0.133(0.144)$ & {$[-0.416,0.150]$} \\
Conscientiousness vs. agreeableness & $-0.175(0.170)$ & {$[-0.509,0.159]$} \\
\hline
\end{tabular}

${ }^{*} p<0.1, \stackrel{* *}{p}<0.05, \stackrel{* * *}{p}<0.01$

\section{Discussion}

\subsection{Research structure}

This study had referred to the theories based on brand image (Park et al., 1986) and customer satisfaction level (Voss et al., 1998) to design the survey questionnaire items. However, the results of the test model for the variables of brand image and customer satisfaction were revealed to be insignificant and to be removed in the research structure. Therefore, the research model is included as the independent variables of service quality satisfaction, the mediator of perceived value, the moderator of personality traits and the dependent variables of customer retention to be explored.

\subsection{Mediated effect}

The empirical results depict that service quality has a direct effect on perceived value, and perceived value has a direct effect on customer retention $\left(\mathrm{H}_{1}, \mathrm{H}_{2}\right)$. The perceived satisfaction level of service quality for the customers is an important driver for perceived value on the consuming process of purchase intentions. This study has also confirmed that the mediator of perceived value positively facilitates the relationship between service quality satisfaction and customer retention $\left(\mathrm{H}_{3}\right)$. The result simply that the service quality satisfaction could assist in enhancing perceived value, and to create a positive synergy effect on customer repurchase and recommendation intentions.

Moreover, when subscribers are opting not to continue their contract but still use the 
operator's service. The mobile operators should not immediately restore their original higher rate. This is because it will result in disappointment for not so active customers to impact their continued usage intention. The mobile operators should take the initiatives to request the users for renewal of the contract, and provide additional benefits to retain the old customers. Furthermore, how to enhance both perceived quality value and competitive prices to improve perceived value are approaches for customer retention and to attract the customers in rival operators to switch solution providers.

\subsection{Moderated effect}

By adding the factor of customer personality traits, this study has validated that the indirect effect of SV-PV-CR is revealed to be different because of personality differentials. The moderator of customer personality traits partially appears the relationship between service quality satisfaction and customer retention through the mediation tool of perceived value $\left(\mathrm{H}_{4}\right)$. There are only two significant differences for the indirect effects of extraversion-neuroticism and the openness to experiences-neuroticism in the personality traits.

The empirical results demonstrated that the more lively and open personalities such as extraversion and openness to experiences will be different from neuroticism to display significant differences of indirect effects. The indirect effects of SQ-PV-CR were contingent on the Big Five personality traits to display a partial moderated effect. It revealed that the service quality satisfaction in the different personality traits affected the perceived value and customer retention, and furthermore to affect the subscribers to be stay or not to stay. This reminds the mobile operators based on the different personality characteristics of targeting markets to employ differentiated marketing strategies.

\section{Conclusion, limitations, and further research}

This study employs a reliable hypothesized measurement model to validate the direct effects of SQ-PV and PV-CR through the mediator of PV to display a mediated effect. For the indirect effect of SQ-PV-CR by adding the factor of the Big Five personality traits, there are only two differences of extraversion-neuroticism and openness to experiences-neuroticism, which are significant to display a partial moderated effect. This research had validated the effects of service quality satisfaction on the customer retention for the mediator of perceived value and the moderator of personality traits in Taiwan's mobile market.

The contribution of this paper is to prove that when a mobile subscriber is satisfied with the current service quality, then he will receive a higher level of perceived value and lead to customer retention. The reliable transmitted network quality and affordable competitive rates provided by the mobile operators are the most important issues for the mobile subscribers. The business strategies are to retain the existing subscribers and to attract subscribers from rival carriers to switch to become loyal customers. The findings have indicated that perceived value assists and strengthens the relation between service quality and customer retention.

Because the measurement of personality characteristics asks the respondents to not combine the sets perquestionnaire item of the detailed personality traits may result in a study limitation. In terms of the research method, the empirical results are derived from a non-probability 
convenience sample for Taiwan's five mobile subscribers. However, the generalization of the findings to all smart phone addicts or non-sampling subscribers might exist as a second study limitation.

When the subscribers face a contractual duration deadline or intention to change their handsets, the handset retail channels have a considerable influence on the decision of whether 'to stay' or 'to switch.' Thus, their comments and suggestions are welcome for engaging in market investigation as a follow-up study recommendation. The OTT service substitutions such as SNS should be noted for future studies. Moreover, due to similar competitive situations and customer characteristics, the global mobile operators could refer to the study results to reconsider delivering higher perceived service quality and developing attractive customer retention planning.

\section{References}

Ahn, J. H., Han, S. P., \& Lee, Y. S. (2006). Customer churn analysis: Churn determinants and mediation effects of partial defection in the Korean mobile telecommunications service industry. Telecommunications $\quad$ Policy, 30(10-11), 552-568. https://doi.org/10.1016/j.telpol.2006.09.006

Alshurideh, M. (2016). Is customer retention beneficial for customers: A conceptual background. Journal of Research in Marketing, 5(3), 382-389. https://doi.org/10.17722/jorm.v5i3.126

Alshurideh, M. (2017). A theoretical perspective of contract and contractual customer-supplier relationship in the mobile phone service sector. International Journal of Business and Management,12(7), 201-210. https://doi.org/10.5539/ijbm.V12n7p201

Anderson, E.W., \& Sullivan, M.W. (1993). The antecedents and consequences of customer satisfaction. Marketing Science, 12(Spring), 125-143. https://doi.org/10.1287/mksc.12.2.125

Anderson, J. C., \& Gerbing, D. W. (1988). Structural equation modeling in practice: A review and recommended Two-step approach. Psychological Bulletin, 103(3), 411-423. https://doi.org/10.1037/0033-2909.103.3.411

Andic, S. (2006). Mobile operators must tune into youth market. New Media Age: pp 7-7.

APT (Asia Pacific Telecom). Available at: http://www.aptg.com.tw (accessed 16March 2017).

Bagozzi, R. P., Yi, Y., \& Phillips, L. W. (1991). Assessing construct validity in organizational research. Administrative Science Quarterly, 36(3), 421-458. https://doi.org/10.2307/2393203

Boulding, W., Kalra, A., Staelin, R., \& Zeithaml, V. A.(1993). A dynamic process model of service quality: from expectations to behavioral intentions. Journal of Marketing Research, 30(1), 7-27. https://doi.org/10.2307/3172510

Business Dictionary. (2016). Available at: http://www.businessdictionary.com/definition/customer-retention.html.

Buttle, F. (1996). Relationship marketing: theory and practice. London, UK, Paul Chapman 
Publishing Ltd. https://doi.org/10.4135/9781446252062

Caruana, A. (2002). Service loyalty: the effects of service quality and mediating role of customer satisfaction. European Journal of Marketing, 36(7/8), 811-828. https://doi.org/10.1108/03090560210430818

Chang, H. H., Wang, Y. H., \& Yang, W. Y. (2009). The impact of e-service quality, customer satisfaction and loyalty on e-marketing: Moderating effect of perceived value. Total Quality Management \& Business $\quad$ Excellence, 20(4), 423-443. https://dx.doi.org/10.1080/14783360902781923

Chen, C. M., \& Liu, H. M. (2017b). The moderating effect of competitive status on the relationship between customer satisfaction and retention. Total Quality Management \& Business Excellence, Published online: $31 \quad$ May 2017. https://dx.doi.org/10.1080/14783363.2017.1333413

Chen, C. M., \& Liu, H. M. (2017a). Exploring the impact of airlines service quality on customer loyalty: Evidence from Taiwan. International Journal of Business and Management, 12(5), 36-50. https://doi.org/10.5539/ijbm.v12n5p36

Chiao, Y. Y. (2017). Taiwan APP users' investigation: The APP rise of game, online shopping, transport, 2017/3/29 issued. Market Intelligence \& Consulting Institute (MIC), Taiwan.

CHT (Chunghwa Telecom Corp.). Available at: http://www.cht.com.tw (accessed 10April 2017).

Cronin, J.J., \& Taylor, S.A. (1992).Measuring Service Quality: A Reexamination and Extension. Journal of Marketing, 56(3), 55-68. https://doi.org/10.2307/1252296

Cronin, J.J., Brady, M.K., \& Hult, G.T.M. (2000).Assessing the effects of quality, value and customer satisfaction on consumer behavioral intentions in service environments. Journal of Retailing, 76(2), 193-218. https://doi.org/10.1016/S0022-4359(00)00028-2

Culiberg, B. (2010). Identifying service quality dimensions as antecedents to customer satisfaction in retail banking. Economic and Business Review, 12(3), 151-166.

Dickinson, D. P. (2015). So many wireless technologies which is the right one for my application, PHOENIX CONTACT. Inspiring Innovations, USA, April 2015.

Dodds, W.B., \& Monroe, K.B. (1985). The effect of brand and price information on subjective product evaluation.Advances on Consumer Research, 12(1), 85-90.

Eshghi, A. Haughton, D., \& Topi, H.(2007). Determinants of customer loyalty in the wireless telecommunications industry. Telecommunications Policy, 31(2), 93-106. https://doi.org/10.1016/j.telpol.2006.12.005

FET (Far EasTone Telecom Co.). Available at: http://www.farestone.com (accessed 11 April 2017).

Fishbein, M., \& Ajzen, I. (1975). Belief, attitude, intentions and behavior: An introduction to 
theory and research. Addison-Wesley, Reading MA.

Fredericks, J. O., \& Slater, J. M. (1998). What does your customer really want? Quality Progress, 31(1), 63-65.

Galetto, M. (2015). What is customer retention? NGDATA. Retrieved from www.ngdata.com/what-is-customer-retention.

Gerpott, T. J., Rams, W., \& Schindler, A. (2001). Customer retention, loyalty, and satisfaction in the German mobile cellular telecommunications market. Telecommunications Policy, 25(4), 249-269. https://doi.org/10.1016/S0308-5961(00)00097-5

Goldberg, L.R. (1993). The structure of phenotypic personality traits. American Psychologist,48(1), 26-34. PMID 8427480. https://doi.org/10.1037/0003-066X.48.1.26

Gordon, H.G., \& McDougall,T.L. (2000). Consumer satisfaction with services: putting perceived value into the equation. Journal of Services Marketing, 14(5), 392-410. https://doi.org/10.1108/08876040010340937

Gounaris, S. (2005). Trust and commitment influences on customer retention: insights from business-to-business services. Journal of Business Research, 58(2), 126-140. https://doi.org/10.1016/S0148-2963(03)00122-X

Grönroos, C. (1997). Keynote paper from marketing mix to relationship marketing- towards aparadigm shift in marketing. Management Decision, 35(4), 322-339. https://doi.org/10.1108/00251749710169729

Hossain, M. A., \& Dwivedi, Y. K. (2015). Determining the consequents of bank's service quality with mediating and moderating effects: An empirical study. Total Quality Management \& Business Excellence, 26(5-6), 661-674. https://doi.org/10.1080/14783363.2013.870783

Hu, H. H., Kandampully, J., \& Juwaheer, T. D. (2009). Relationships and impacts of service quality, perceived value, customer satisfaction, and image: An empirical study. The Service Industries Journal, 29(2), 111-125. https://doi.org/10.1080/02642060802292932

Jones, T. O., \& Sasser, W. E. Jr. (1995). Why satisfied customers defect. Harvard Business Review, 73(6), 88-99.

Kristensen, K., Martensen, A., \& Gronholdt, L. (1999). Measuring the impact of buying behavior on customer satisfaction. Total Quality Management, 10(4/5), 602-614. https://doi.org/10.1080/0954412997587

Kuo, Y. F., Wu, C. M., \& Deng, W. J. (2009). The relationships among service quality, perceived value, customer satisfaction, and post-purchase intention in mobile value-added services. Computers in Human Behavior, 25(4), 887-896.

Lai, W. T., \&Chen, C. F. (2011). Behavioral intentions of public transit passengers-The roles of service quality, perceived value, satisfaction and involvement. Transport Policy, 18(2), 318-325. https://doi.org/10.1016/j.tranpol.2010.09.003 
Lee, M. C. (2006). Applying TQM, CMM and ISO 9001 in knowledge management for software development process improvement. International Journal of Services and Standards, 2(1), 101-115. https://doi.org/10.1504/IJSS.2006.008161

McCrae, R. R., \&Costa P. T. Jr. (1987). Validation of the Five-Factor Model of personality across instruments and observers. Journal of Personality and Social Psychology, 52(1), 81-90. https://doi.org/10.1037/0022-3514.52.1.81

Metcalf, L. E., Frear, C. R., \& Krishnan, R. (1992). Buyer-Seller Relationships: An Application of the IMP Interaction Model. European Journal of Marketing, 26(2), 27-47. https://doi.org/10.1108/03090569210010022

MIC (Market Information Center).Taiwan, Available at: http://www.mic.iii.org.tw (accessed 12December 2015).

Millward Brown Co. a survey company. Available at: http://www.millwardbrown.com (accessed 25March 2017).

MTC, Statistics Dept., of Ministry of Transportation and Communications (MTC). Taiwan, Available at:http://www.motc.gov.tw(accessed 12 March 2017).

NCC (National Communication Committee). Taiwan, Available at:http://www.ncc.gov.tw.(accessed 18 February 2017).

Oliver, R.L. (1980). A cognitive model for the antecedents and consequences of satisfaction. Journal of Marketing Research, 17(4), 460-469. https://doi.org/10.2307/3150499

Oliver, R.L., \&Bearden, W.O. (1985). Disconfirmation processes and consumer evaluations in product usage. Journal of Business Research, 13(3), 235-246. https://doi.org/10.1016/0148-2963(85)90029-3

Parasuraman, A., \& Grewal, D. (2000). The impact of technology on the quality-value-loyalty chain: A research agenda. Journal of the Academy of Marketing Science, 28(4), 168-174. https://doi.org/10.1177/0092070300281015

Parasuraman, A., Zeithaml, V.A., \& Berry, L. L. (1985). A conceptual model of service quality and its implication. Journal of Marketing, 49(Fall), 41-50. https://doi.org/10.2307/1251430

Parasuraman, A., Zeithaml,V.A., \& Berry, L.L. (1988).SERVQUAL: a multiple-item scale for measuring customer, perceptions of service quality. Journal of Retailing, 64(1),12-40.

Park, C.W., Jaworski, B.J., \& Maclnnis, D.J. (1986). Strategic brand concept-image management. Journal of Marketing, 50(4), 135-145. https://doi.org/10.2307/1251291

Petrick, J. F. (2002). Development of a multi-dimensional scale for measuring the perceived value of a service. Journal of Leisure Research, 34(2), 119-34.

Raquel, Sánchez-Fernández, \& Ángeles, M.Iniesta-Bonillo. (2007).The concept of perceived value: A systematic review of the research.Marketing Theory, 7(2007), 427-451. 
https://doi.org/10.1177/1470593107083165

Santhanamery, T., \& Ramayah, T. (2013). The Effect of Personality Traits on User Continuance Usage Intention of e-Filing System. Journal of Economics, Business and Management, 1(1), 25-28. https://doi.org/10.7763/JOEBM.2013.V1.6

Sathye, M. (1999). Adoption of Internet banking by Australian consumers: an empirical investigation. The International Journal of Bank Marketing, 17(7), 324-334. https://doi.org/10.1108/02652329910305689

Seth, N., Deshmukh, S.G., \& Vrat, P. (2005). Service quality models: a review. International Journal of Quality \& Reliability Management, 22(9), 913-949. https://doi.org/10.1108/02656710510625211

Shurideh, A., \& Turki, M. (2010). Customer Service Retention: A Behavioral Perspective of the UK Mobile Market. Doctoral thesis, Durham University. Available at Durham E-Theses online: http://etheses.dur.ac.uk/552/

Srisawatsakul, C., Quirchmayr, G., \& Papasratorn, B. (2014). A Pilot Study on the Effects of Personality Traits on the Usage of Mobile Applications: A Case Study on Office Workers and Tertiary Students in the Bangkok Area. Recent Advances in Information and Communication Technology, IC2IT2014, 145-155. https://doi.org/10.1007/978-3-319-06538-0_15

Sweeney, J.C., \& Soutar, G.N. (2001). Consumer perceived value: The development of a multiple item scale. Journal of Retailing, 77(2), 203-220. https://doi.org/10.1016/S0022-4359(01)00041-0

Toegel, G., \& Barsoux, J. L. (2012). How to become a better leader. MIT Sloan Management Review, 53(3), 51-60.

TSTAR (Taiwan Star Telecom). Available at: http://www.tstartel.com.tw (accessed 10May 2017).

TWM (Taiwan Mobile Co., Ltd.). Available at: http://www.taiwanmobile.com (accessed 18 March 2017).

Venetis, K. A., \& Ghauri, P. N. (2004). Service quality and customer retention: building long-term relationships. European Journal of Marketing, 38(11/12), 1577-1598, https://doi.org/10.1108/03090560410560254

Voss, G.B., Parasuraman, A., \& Grewal, D. (1998). The roles of price, performance, and expectations in determining satisfaction in service exchanges. Journal of Marketing, 62(4), 46-61. https://doi.org/10.2307/1252286

Yang, Z., \& Fang, X. (2004). Online service quality dimensions and their relationships with satisfaction: a content analysis of customer reviews of securities brokerage services. International Journal of Service Industry Management, 15(3), 302-326. https://doi.org/10.1108/09564230410540953

Zeithaml, V.A. (1988). Consumer perceptions of price, quality and value: a means-end model 
and synthesis of evidence. Journal of Marketing, 52(3), 2-22. https://doi.org/10.2307/1251446

Zhou, T., \& Lu, Y. (2011). The Effects of Personality Traits on User Acceptance of Mobile Commerce. International Journal of Human-Computer Interaction, 27(6), 545-561, https://doi.org/10.1080/10447318.2011.555298

\section{Appendix 1}

A.1 Service Quality (level of satisfaction or dissatisfaction)

\section{A.1.1Tangible attributes}

1. The business facilities of the retail store channels are new and the space planning feels comfortable.

2. Mobile broadband communication equipment and base stations have been built and have a high coverage ratio.

3. The mobile handset selection is diversified and related accessories are adequate to choose from.

\section{A.1.2 Reliability}

4. The upload and download transmission speed of the mobile broadband network are reliable and stable.

5. The communication quality of the mobile phone and Internet are reliable.

6. Even in remote areas, the mobile communication quality is still reliable.

\section{A.1.3 Responsiveness}

7. The waiting time is acceptable for the retail store and online customers.

8. Service staff could immediately respond to the customer requirements.

9. Customer complaints are handled as soon as possible.

\section{A.1.4 Assurance}

10. Even during the peak time the completed connection rates of mobile phones are still high.

11. The interrupted probabilities of mobile communications are very low.

12. The staff has good communication skills in professional services.

\section{A.1.5Empathy}

13. The band width speeds match with the rates compared to competitors is appropriate.

14. The service staff takes the initiative to ease customer emotions when waiting for service.

15. The company strives to satisfy the customers for their individual needs.

A.2 Perceived Value (level of agreement or disagreement)

\section{A.2.1 Perceived quality value}


16. Will take the initiative to teach customers to operate the different functions of the mobile phones and value-added services.

17. This mobile operator could provide me with better Internet quality over other operators.

\section{A.2.2 Emotional value}

18. The service attitude of the staff is friendly and makes me feel satisfied.

19. The process design of applications and renewals allow customers to not wait too long.

\section{A.2.3 Social value}

20. The mobile network system of my current mobile operator has a positive reputation.

21. By utilizing the mobile services of my operator allow me to feel their courteous attitudes.

\section{A.2.4 Price}

22. The data and voice bundling rates support a variety of programs in line with my needs.

23. The flat rate bundling voice with data is affordable to me.

A.3 Customer Retention (level of agreement or disagreement)

\section{A.3.1 Repurchase intention}

24. The network quality and acceptable rates provided by my operator allows me to continue selecting them as my service provider of choice.

25. I will continue to use this operator due to attraction to their preferential programs.

26. I will continue to extend my contract with this mobile operator after my contract expires.

\section{A.3.2 Recommendation intention}

27. I will recommend my friends and families to choose this operator due to free of charge calling and other services within their network.

28. The service experience with this mobile operator is positive and I wish to share this positive experience with others.

\section{A.4 Personality Traits}

Which personality trait is closest to your type? Please select one.

1. $\square$ Neuroticism 2. Extraversion 3. $\square$ Openness 4. $\square$ Agreeableness 5. $\square$ Conscientiousness

\section{A.5Purchase Decision}

1. After the contractual duration, what is your usage intention?

$\square$ To stay with the current mobile service operator. $\square$ To switch to another mobile operator.

2. Which mobile operator is your current service provider? 